\title{
Beneficial Effects of Ginger as Hypoglyemic, Hypolipidemic, Anti-obesity, Anti-oxidant, and Anti- inflammatory Agent in Adult Female albino Rats
}

\author{
Mona F. El-Karn*, Sahar EM. El-Deek and Amany Osama \\ Medical Physiology * and Medical Biochemistry Departements \\ Faculty of Medicine, Assiut University
}

\begin{abstract}
Ginger is one of the more commonly used herbal supplements. Although often consumed for culinary purposes, it is taken by many patients to treat a variety of conditions. Currently, there is a renewed interest in ginger, and several scientific investigations aimed at isolation and identification of active constituents, and verification of the basis of the use of ginger in some of several diseases and conditions. The present work aimed to evaluate the beneficial effects of ginger as hypoglycemic, hypolipidemic, anti-obesity, anti-oxidant and anti-inflammatory agent. The study included 4 groups of rats: control group (group I), high fat diet-induced obesity rats (group II), alloxan-induced diabetic rats (group III) and carrageenininduced inflammation in rats (group IV). The ginger was administered orally in a dose of about $500 \mathrm{mg} / \mathrm{Kg}$ body weight for 8 weeks. Serum was analyzed for contents of blood glucose, cholesterol, triglyceride, LDL-cholesterol, HLD-cholesterol, nitric oxide, lipid peroxide, prostaglandin $E_{2}$ and C-reactive protein. Results: The high fat diet-induced obesity rats group treated with ginger showed significant reduction in body weight $(p<0.0001)$. Both high fat diet -induced obesity rats group and alloxaninduced diabetic rats group treated with ginger showed significant reduction in serum levels of glucose, cholesterol, triglyceride and LDL-cholesterol and significant increase in serum level of HDL-cholesterol ( $p<0.0001$ for each). In addition, there was significant reduction in the serum levels of nitric oxide and lipid peroxide $(p<0.0001$ for each). Finally carrageenin-induced inflammation in rats group treated with ginger showed significant reduction in serum levels of prostaglandin $E_{2}$ and $C$ reactive protein ( $p<0.0001$ for each). In conclusion: The results indicate that ginger has potential beneficial effects in conditions of obesity, diabetic dyslipidemia and could be considered as supplementary herbal therapy for prevention or treatment of obesity and diabetes. It protects tissues from lipid per-oxidations and inflammation and might be a promising candidate in prevention and or therapy for inflammation.
\end{abstract}

\section{INTRODUCTION}

Obesity is one of the fastestgrowing major diseases in many areas of the world. More than one half of United States men and women aged > 20 years are considered overweight and nearly one fourth are clinically obese $^{(\mathbf{1})}$. Obesity results from an imbalance between energy intake and expenditure and it is closely associated with life-style-related diseases such as hyperlipidemia, hypertension, atherosclerosis and noninsulin-dependant diabetes mellitus and with increased risk of coronary heart disease ${ }^{(2)}$. Cardiovascular diseases constitute the main cause of 
morbidity and mortality in diabetes mellitus. Diabetic individuals have two-to four-folds increased risk of clinical atherosclerotic diseases. Dyslipidemia is proved to be the most modifiable risk factor contributing to atherosclerosis in diabetes. Furthermore, there is widespread acceptance of a possible generation of reactive oxygen species in diabetes as a result of hyperglycemia(3). Active oxygen molecules have been demonstrated to play important role in the inflammation process and despite the presence of strong antioxidant defense mechanisms, the damage to DNA and other biomolecules accumulate during the lifetime of organism $^{(4)}$.

On the other hand, inflammation is associated with large range of mediators that initiate the inflammatory response, recruit and activate other cells to the site of inflammation and subsequently resolve the inflammation. In the presence of appropriate stimuli, gene expression and production of cytokine and reactant protein will occur, leading to the initiation of an inflammatory response ${ }^{(5)}$. The inability of the modern synthetic approach to provide a satisfactory answer has led to shift in focus to alternative forms of therapy based on drugs derived from plants. Herbs and spices are generally considered safe and proved to be effective against various human ailments ${ }^{(3,4)}$. Ginger (Zingiber officinale Roscoe) is one of the most widely used spices and is reputed to have medical properties against many diseases. It contains several hundred valuable compounds and new constituents are still being found. The proportion of each in a sample of ginger depends upon country of origin, commercial processor and whether the ginger is fresh, dried or processed ${ }^{(\mathbf{6})}$. Pharmacologically, the plant has been investigated for its hypoglycemic, hypolipidemic, antimicrobial, antiinflammatory, antioxidant, and cytotoxic activities $^{(3,7)}$.

\section{Aim of the work:}

The aim of the present study is to evaluate the beneficial effects of ginger in condition of hyperglycemia associated with hyperlipidemia and obesity and to investigate the effect of ginger as antioxidant and antiinflammatory agent.

\section{MATERIALS \& METHODS}

1.Plant material: Dried Zingiber (ginger) was purchased from a local market. It was give in a dose of about $500 \mathrm{mg} / \mathrm{kg}$ orally added to the food.

2. Animals: The study was conducted on white adult female Wistar albino rats. Animals were obtained from the Animal House of Faculty of Medicine, Assiut University. Their weight ranged between 115-140 grams at the beginning of the experiment. They were housed in groups in standard environmental condition including good aerated room with suitable temperature. The experiment included 80 rats which were divided into 4 groups of 20 rats each.

Group I (control group): rats received normal standard rodent food and water for 8 weeks were selected for the study as normal control. 
Group II: rats were administered high fat diet composed of, corn oil $40 \mathrm{~g} /$ $100 \mathrm{~g}$ food, cornstarch $10 \mathrm{~g} / 100 \mathrm{~g}$ food. Romy cheese $25 \mathrm{~g} / 100 \mathrm{~g}$ food, sugar 9 $\mathrm{g} / 100 \mathrm{~g}$ food, casein 36g/100g food and vitamin and mineral mixture $1 \mathrm{~g} / 100 \mathrm{~g}$ food $^{(8)}$. This group was further divided into 2 subgroup each consisting of 10 rats. Group II (a) rats without ginger treatment and group II (b) rats with ginger treatment added to the diet in a dose of $500 \mathrm{mg} / \mathrm{kg}$ body weight for 8 weeks.

Group III: rats with Alloxan induced diabetes. $100 \mathrm{mg} / \mathrm{kg}$ of drug was injected intramuscularly in a single dose. The drug was dissolved in 0.5 $\mathrm{ml}$ saline and the animals were tested for diabetes after 5 days. The animals were considered diabetic when their blood glucose level was $300 \mathrm{mg} / \mathrm{dl}$ or more $^{(9)}$.This group was further divided into 2 subgroups each consisting of 10 rats. Group III (a) rats without ginger treatment and group III (b) rats with ginger treatment for 8 weeks.

Group IV: rats with induction of inflammation. $0.1 \mathrm{ml}$ of $(0.5-2 \%)$ of Carrageenin solution was injected into the planter surface of the right hind paw. Inflammation peak developed 24 hours after injection. To monitor the development of inflammation, planter circumference of the injected paw was measured $^{(\mathbf{1 0 )}}$. Also, this group was divided into 2 subgroups each group consisting of 10 rats.

Group IV (a) rats without ginger treatment and group IV (b) rats with ginger treatment for 8 weeks.

Blood collection and biochemical estimation:

At the end of the experiment, the animals of each group were sacrificed and blood was collected, centrifuged in $500 \mathrm{rpm}$ for 15 minutes and the serum from each sample was kept at $20{ }^{\circ} \mathrm{C}$ for determination of biochemical parameters.

Serum glucose was determined by the method of Weissman ${ }^{(11)}$. Serum total cholesterol and triglyceride were determined by the methods of Allian et $\mathbf{a l}^{(\mathbf{1 2 )}}$ and McGowan et al, $^{(13)}$ respectively. Serum LDL-cholesterol and HDLcholesterol were determined by the methods of Assmann et al, $^{(14)}$ and Bergmenyer, ${ }^{(15)}$ respectively.

Nitric oxide was determined by the method of Buege and Aust, ${ }^{(16)}$. Also lipid peroxide was determined according to the method of Bezooijen et $\mathbf{a l}^{(17)}$.

On the other hand, Prostaglandin $\mathrm{E}_{2}$ $\left(\mathrm{PGE}_{2}\right)$ was determined by an ELISA kit for quantitative determination of prostaglandin E, Cat. No. KGE004 manufactured by $\mathrm{R}$ and $\mathrm{D}$ system Minneapolis, United States, America. The measurement was performed according to the method described by Brueggemeir et $\mathbf{a l}^{\left({ }^{(18)}\right.}$. Also, Creactive protein (CRP) was determined by an ELISA kit for quantitative determination of Creactive protein. The kit was manufactured by DiaMed EuroGen, 2300 Turnhout, Belgium. The measurement was performed according to the method described by Mitra and panja ${ }^{(19)}$.

\section{Statistical analysis:}

It was performed using SPSS statistical program (statistical package for social science, version 11) for analyzing the result data. All the studied parameters concentrations were presented as mean \pm SD. The 
one way ANOVA was used to determine the significance of the difference between the groups. Student t-test was used to compare between two groups. $\mathrm{P}<0.05$ was considered significant.

\section{RESULTS}

Rats of group II a (rats with high fat diet) showed significant increase in body weight, serum glucose, cholesterol, triglyceride, and LDLcholesterol levels and significant decrease in serum HDL-cholesterol levels as compared to group I (control group) ( $p<0.0001$ for each). Animals of group II (b) (rats treated with ginger) showed significant reduction in body weight and reduction in the serum level of glucose, cholesterol, triglyceride, and LDL-cholesterol and increase in the serum level of HDLcholesterol as compared with group II (a) $(\mathrm{p}<0.0001$ for each) (Table 1$)$.

Animals of group III (rats with alloxan induced diabetes) showed significant increase in blood glucose, cholesterol, triglyceride, LDLcholesterol levels and reduced serum level of HDL-cholesterol as compared with group I $(\mathrm{p}<0.0001)$. Animals of group III (b) (rats treated with ginger) showed significant reduction in serum levels of glucose, cholesterol, triglyceride, LDL-cholesterol and significant increase in serum level of HDL- cholesterol as compared with group III (a) $([<0.0001$ for each) (Table 2).

Lipid peroxidation as reflected by lipid peroxide levels and nitric oxide levels were higher in group II (a) and group III (a) as compared with group I $(p<0.0001$ for each). Ginger supplementation caused significant reduction in the levels of lipid peroxide and nitric oxide as compared by group II (b) and group III (b) ( $<<0.0001$ for each) (Table 3).

Animals of group IV (rats with carrageenin induced inflammation) showed significant increase in inflammatory markers 24 hours after injection of the drug as compared with group I ( $<<0.0001$ for each). Animals with group IV (b) showed significant reduction in inflammatory markers as compared with group IV (a) $(\mathrm{p}<.0001$ for each) (Table 4).

Table (1): Effects of ginger on body weight, serum glucose and serum lipid profile on high fat diet-induced obesity rats

\begin{tabular}{|c|c|c|c|c|c|c|c|}
\hline Group & No & $\begin{array}{l}\text { Body. } \\
\text { Wt.g. }\end{array}$ & $\begin{array}{l}\text { Glucose } \\
\mathrm{mg} / \mathrm{dl}\end{array}$ & $\begin{array}{l}T C \\
m g / d l\end{array}$ & $\begin{array}{l}T G \\
m g / d l\end{array}$ & $\begin{array}{l}L D L c \\
m g / d l\end{array}$ & $\begin{array}{l}\text { HDLc } \\
\mathrm{mg} / \mathrm{dl}\end{array}$ \\
\hline & 20 & $123 \pm 2.5$ & $91.3 \pm 7.0$ & $88.8 \pm 2.7$ & $50.4 \pm 3.8$ & $38.6 \pm 2.8$ & $32.4 \pm 3.3$ \\
\hline & 10 & & & & & & $20.0 \pm 3.8$ \\
\hline $\mathrm{P}^{*}<$ & & & & 0.0001 & & & 0.0001 \\
\hline & 20 & $180 \pm 2.4$ & $240.3 \pm 33$ & $93.9 \pm 4.4$ & $59.3 \pm 4.9$ & $44.7 \pm 6.6$ & $31.1 \pm 4.2$ \\
\hline $\mathrm{P}^{* *}<$ & & 0.001 & 0.0001 & 0.0001 & 0.0001 & 0.0001 & 0.0001 \\
\hline
\end{tabular}

$P^{*}$ : When group II (a) compared with group I.

$P^{* *}$ : when group II (b) compared with group II (a).

Group I: control group. $T C=$ Total cholesterol. $T G=$ Triglycerides

Group II (a): High fat diet-induced obesity rats without ginger treatment.

Group II (b): High fat diet-induced obesity rats with ginger treatment. 
Table (2): Effects of ginger on serum glucose and serum lipid profile on alloxaninduced diabetic rats

\begin{tabular}{l|llllll}
\hline Group & No & $\begin{array}{l}\text { Glucose } \\
\boldsymbol{m g} / \boldsymbol{d l}\end{array}$ & $\begin{array}{l}\text { TC } \\
\boldsymbol{m g} / \boldsymbol{d l}\end{array}$ & $\begin{array}{l}\text { TG } \\
\boldsymbol{m g} / \boldsymbol{d l}\end{array}$ & $\begin{array}{l}\text { LDLc } \\
\mathbf{m g} / \mathbf{d l}\end{array}$ & $\begin{array}{l}\text { HDLc } \\
\mathbf{m g} / \boldsymbol{d} \mathbf{l}\end{array}$ \\
\hline Group I & 20 & $91.3 \pm 7.0$ & $88.8 \pm 2.7$ & $50.4 \pm 3.8$ & $38.6 \pm 2.8$ & $32.4 \pm 3.3$ \\
Group IIa & 10 & $408.0 \pm 49.1$ & $127.1 \pm 5.2$ & $128.6 \pm 3.9$ & $91.6 \pm 12.7$ & $20.1 \pm 3.0$ \\
$\mathrm{P}^{*}<$ & & 0.0001 & 0.0001 & 0.0001 & 0.0001 & 0.0001 \\
Group IIb & 20 & $280.3 \pm 24.9$ & $96.7 \pm 3.6$ & $57.7 \pm 3.2$ & $46.3 \pm 2.3$ & $30.6 \pm 4.3$ \\
$\mathrm{P}^{* *<}$ & & 0.0001 & 0.0001 & 0.0001 & 0.0001 & 0.0001 \\
\hline
\end{tabular}

$P^{*}:$ When group II (a) compared with group I.

$P^{* *}$ : when group II (b) compared with group II (a).

Group I: control group. $T C=$ Total cholesterol. $\quad T G=$ Triglycerides

Group II (a): High fat diet-induced obesity rats without ginger treatment.

Group II (b): High fat diet-induced obesity rats with ginger treatment.

Table (3): Effects of ginger on nitric oxide and lipid peroxide in high fat dietinduced obesity rats and in alloxan-induced diabetic rats.

\begin{tabular}{l|lll}
\hline Groups & No. & Nitric oxide $\boldsymbol{\mu m o l . / \text { . }}$ & Lipid peroxide $\boldsymbol{\mu m o l . /}$ \\
\hline Group I & 20 & $16.7 \pm 1.6$ & $5.9 \pm 0.8$ \\
Group II a & 10 & $27.0 \pm 1.4$ & $9.5 \pm 1.2$ \\
$\mathrm{P}^{*}<$ & & $<0.0001$ & $<0.0001$ \\
Group II b & 10 & $20.4 \pm 1.0$ & $6.1 \pm 0.7$ \\
$\mathrm{P}^{* *<}$ & & 0.0001 & 0.0001 \\
Group III a & \multirow{2}{*}{10} & $26.7 \pm 0.9$ & $10.4 \pm 1.4$ \\
P***< & & 0.0001 & 0.0001 \\
Group III b & 10 & $20.3 \pm 1.1$ & $6.2 \pm 0.6$ \\
$\mathrm{P}^{* * * *<}$ & & 0.0001 & 0.0001 \\
\hline
\end{tabular}

$P^{*}$ : When group II (a) compared with group I.

$P^{* *}$ : When group II (b) compared with group II (a).

$P^{* * *}$ : When group III (a) compared with group I.

$P^{* * * * *}$ When group III (b) compared with group III (a).

Table (4): Effects of ginger on inflammatory mediators on carrageenin-induced inflammation in rats

\begin{tabular}{l|lll}
\hline Groups & No. & $\boldsymbol{P G E}_{2} \boldsymbol{\mu g} / \boldsymbol{m L}$ & $\boldsymbol{C R P} \mathbf{m g} / \mathbf{l}$ \\
\hline Group I & 20 & $2.9 \pm 0.4$ & $4.04 \pm 1.4$ \\
Group IVa & 10 & $11.5 \pm 1.5$ & $6.05 \pm 2.9$ \\
P*< & & 0.0001 & 0.001 \\
Group IVb & 10 & $5.9 \pm 0.3$ & $4.97 \pm 2.3$ \\
P $^{* *}$ & & 0.0001 & 0.001 \\
\hline
\end{tabular}

$P^{*}$ : When group IV compared with group I.

$P^{* *}$ : when group IV (a) compared with group IV (b).

Group IV (a): Carrageenin-induced inflammation in rats without ginger treatment.

Group IV (b): Carrageenin-induced inflammation in rats with ginger treatment.

PGE2: prostaglandin $E_{2}$. CRP: $C$ - reactive protein. 


\section{DISCUSSION}

The inability of the modern synthetic approach to provide a satisfactory answer for treatment of several diseases has led to shift in focus to alternative forms of therapy based on drugs derived from plants. Zingiber officinal Roscore (ginger) is one of the most widely used spices and is reputed to have medical properties for treatment of arthritis, rheumatism, pains, constipation, vomiting, hypertension and infectious diseases ${ }^{(3,7)}$. Currently, there is a renewed interest in ginger, and several scientific investigations aimed at isolation and identification of active constituent of ginger, scientific verification of its pharmacological actions and of its constituents, and verification of basis of the use of ginger in some of several diseases ${ }^{(7)}$. The main pharmacological actions of ginger include anti-tumorigenic, antiinflammatory, ant-apoptotic, antihyperglycemic, anti-lipidemic and anti-emetic action. Ginger is strong anti-oxidant substance and may prevent generation of free radicals. It is considered a safe herbal medicine with only few and insignificant adverse effects ${ }^{(3)}$.

In the present study, the rats taking high fat diet showed significant increase in weight and higher levels of glucose, cholesterol, triglyceride and LDL-cholesterol and reduction in HDL-cholesterol as compared with control group. Treatment with ginger to obese rats produced a significant reduction in weight and in the serum levels of glucose, cholesterol, triglyceride and LDL-cholesterol and increased serum level of HDL- cholesterol. These results were in agreement with those of Goyal and Kadnur $^{(1)}$ who found that treatment with methanolic and ethyl acetate extracts of ginger to obese mice, produced a significant reduction in serum glucose levels and reduction in elevated lipid levels associated with hyperglycemia and hyperinsulinemia. Also, Han et al, ${ }^{(2)}$ reported that body weight was significantly lowered in mice fed with the high fat diet containing $3 \%$ aqueous extract of ginger than in the controls fed with the high fat diet. In addition, Thomson et al. ${ }^{(20)}$, Verma et al. ${ }^{(21)}$, and Nicoll and Henein, ${ }^{(6)}$ reported that in animals which were diabetic or have fed a high lipid diet, ginger significantly lowered serum total cholesterol, LDL, VLDL, triglyceride and phospholipids. Also there were significant reduction in atherosclerotic lesions and associated foam cell formation and raised HDL as effectively as conventional hypolipidemic drugs.

5-hydroxytryptamine receptor modulators were reported to have beneficial effects in condition of obesity. It plays a crucial role in controlling appetite; hence drugs modulating 5-HT function and thereby controlling the appetite are useful in conditions of obesity. Ginger is reported to contain 5-HT modulators and its effects in reducing elevated glycemic and lipid levels and reduction in body weight may be due to its 5-HT modulatory effects ${ }^{(\mathbf{1})}$. On the other hand, Han et al. ${ }^{(2)}$ suggested that the anti-obesity effect of aqueous extract of ginger may be due in part to the inhibition of intestinal absorption 
of dietary fat by the active compounds of ginger.

The present study was to investigate the effect of ginger on diabetic dyslipidemia induced by alloxan in rats. The study revealed the significant anti-hyperglycemic activity of ginger. Furthermore, treatment with ginger also produced significant reduction in serum cholesterol, triglyceride and LDL-cholesterol. These results were in agreement with the results of Bhandari et al. ${ }^{(3)}$ who found that ethanolic extract of ginger reduced glucose and lipid levels indicating the hypoglycemic and lipid lowering activity of the tested drug. Also, Al-Amin, et al. ${ }^{(22)}$ reported that diabetic rats showed significant increase in serum levels of glucose, cholesterol and triglycerides. They also, reported that an aqueous extract of raw ginger effectively lowers serum glucose, cholesterol and triglyceride levels in diabetic rats. A similar result was reported by Akhani et al. $^{(23)}$, Kadnur and Goyal ${ }^{(24)}$, Ojewole $^{(25)}$ and Nicoll et al. ${ }^{(6)}$. In contrast, in another study, nondiabetic patients with coronary artery diseases showed no decrease in their blood lipid or sugar levels when treated with a daily dose of $4 \mathrm{~g}$ powdered ginger for a period of 3 month ${ }^{(26)}$.

Aldose reductase inhibitors are now considered to have remarkable potential for treatment of diabetes and its complications without increased risk of hypoglycemia. It has recently been reported that the assay for aldose reductase inhibitors in ginger led to isolation of five active compounds including 2-(4-hydroxy-3methoxyphenyl) ethanol and 2-(4- hydroxy-3-methoxyphenyl) ethanoic acid. These tow compounds were good inhibitors of recombinant human aldose reductase $^{(7)}$. Furthermore, these compounds significantly suppressed not only sorbitol accumulation in human erythrocytes, but also lens galactitol accumulation in 30\% of galactose-fed cataract rats, suggesting that protection against or improvement of diabetic complication could be achieved with dietary supplement of either ginger or extract containing aldose reductase inhibitors $^{(7)}$. Al-Amin et al. $^{(22)}$ reported that the hypoglycemic action of ginger may be due to effects involving serotonin receptors, an increased in pancreatic secretion of insulin from B cells or release of bound insulin. In addition Verma et al. ${ }^{(21)}$ and Nicoll and Henein ${ }^{(6)}$ reported that ginger acts on the liver to reduce cholesterol biosynthesis and may stimulate cholesterol conversion to bile acids and increased its fecal excretion.

In the present study, rats taking high fat diet and animals with alloxan induced diabetes showed significant increase in nitric oxide and lipid peroxide. Treatment with ginger to these two groups led to significant decrease in the levels of nitric oxide and lipid peroxide. These results were in agreement with those of Lppoushi et al. ${ }^{(27)}$ and Imanishi et al. ${ }^{(28)}$ who demonstrated that ginger inhibit nitric oxide production on macrophages and western blot analysis showed markedly decreased inducible nitric oxide synthase protein levels after treatment by ginger. The inhibitory mechanism of ginger on inducible nitric oxide synthase induction in 
activated macrophages remains unclear but it may inhibits epidermal growth factor and activator protein-1 that cause inhibition of nitric oxide synthase enzyme induction in stimulated macrophages ${ }^{(27)}$. Also, Ajith et al. ${ }^{(4)}$ found that treatment with ginger significantly enhanced the hepatic antioxidant activity including hepatic catalase, glutathione peroxidase and sodium dismutase and the hepatoprotective effect of ginger is mediated either by preventing the decline of hepatic antioxidant status or due to its direct free radical scavenging capacity.

Asnani and Verma ${ }^{(29)}$ and Bhandari et al. ${ }^{(3)}$ showed that an addition of aqueous extract of ginger to the p-hydroxybenzoic acid induced lipid peroxidation significantly reduced this lipid peroxidation. In addition, Suganthi et al. ${ }^{(30)}$ found that administration of spices mixture including ginger along with fructose diet reduced the levels of peroxidation markers in tissues and improved the antioxidant status and the positive effects on oxidant-antioxidant balance. This could be attributed to the active constituents of ginger. Recently, it has been showed that 6gingerol is endowed with strong antioxidant action both in vivo and vitro and this makes it a very effective agent for prevention of ultra violet induced reactive oxygen species production $^{(31)}$.

In the present study, rats with carrageenin induced inflammation showed significant increase in the levels of inflammatory mediator as prostaglandin $\mathrm{E}_{2}$ and C-reactive protein. Treatment with ginger to this group showed significant decrease in the levels of inflammatory mediator. These results were in agreement with de Lemos et al. ${ }^{\text {(32) }}$ who found that Creactive protein was increased in a condition of low grade systemic inflammation as in cardiovascular diseases and type 2 diabetes. Also, Amezcua-Guerra et al. ${ }^{\left({ }^{3}\right)}$ showed that C-reactive protein is a non specific acute phase protein that has been used as inflammatory marker and increased level of it cause induction of cytokines and prothrombotic factors. C-reactive protein did not alter endothelial nitric oxide synthase protein expression but increased protein expression of GTP cyclohydrolase-1, the rate limiting enzyme in the synthesis of tetrahydrobiopterin, the nitric synthase cofactors $^{(34)}$. In addition, Thomson et al. ${ }^{(20)}$ and Ojewole, ${ }^{(25)}$ confirmed the inhibitory action of ginger on prostaglandins when they reported that either oral or intraperitoneal administration of ginger (500 mg) given to rats daily for 4 weeks was effective in significantly reducing serum prostaglandin. Grzanna et al. ${ }^{(35)}$ showed that ginger and some of its constituents is effective against cytokines synthesized and secreted at the site of inflammation and it was found to inhibit the induction of several genes involved in the inflammatory response and can inhibit beta-amyloid peptide-induced cytokines and chemokines expression. He also reported that ginger shares pharmacological properties with nonsteroidal anti-inflammatory drugs through suppression of prostaglandin biosynthesis by inhibiting cyclooxygenase-1 and cyclooxygenase-2. Ginger also 
suppresses leukotriene biosynthesis by inhibiting 5-lipoxygenase enzyme and these observations may have better therapeutic profile and fewer side effects than non steroidal antiinflammatory drugs ${ }^{(35)}$. Also, Lantz et al. ${ }^{(5)}$ found that organic extract of ginger and compounds found in ginger are highly effective in inhibit lipopolysaccharides-induced

production of prostaglandins E2 and these compounds appear to be not only inhibit cyclo-oxygenase-2 enzyme activity, but are also able to alter cyclo-oxygenase-2 mRNA levels. In addition, Tripathi et al. ${ }^{\text {(36) }}$ showed that ginger not only inhibit proinflammatory cytokine production by macrophages but also decreased production of pro inflammatory mediators.

In conclusion the present data suggest that ginger has potential beneficial effects in condition of obesity, hyperglycemia and hyperlipidemia. In addition to decrease serum level of glucose and lipid, ginger can also significantly retard gain in body weight. Based on these beneficial effects, ginger can be considered as supplementary herbal therapy for prevention and treatment of obesity, treatment of diabetes and hyperlipidemia. Also ginger has antiinflammatory effects and can protect tissues from lipid peroxidation. Taken together, these results suggest that ginger has potent antioxidant and antiinflammatory potentials, and may be a promising candidate in prevention and or therapy for inflammation associated carcinogenesis. Further study is needed to investigate the active compounds of ginger responsible for the observed beneficial effects.

\section{REFERENCES}

1. Goyal RK, Kandnur SV. (2006): Beneficial effects of Zingeber officinale on gold thioglucose induced obesity. Fitoterapia 77: 160-163.

2. Han (a) LK, Gong XJ, Kawano S, Saito M, Kimura $Y$, and Okuda H.(2005): Anti-obesity actions of Zingiber officinale Roscoe. Yakugaku Zasshi. 125: 213-7.

3. Bhandari $U$, Kanojia $R$, and Pillal KK. (2005): Effect of ethanolic extract of Zingiber officinale on dyslipidemia in diabetic rats. J. Ethnopharm. 97: 227-230.

4. Ajith TA, Hema U, and Aswathy MS. (2007): Zingiber officinale Roscoe prevent acetaminophen-induced acute hepatotoxicity by enhancing hepatic antioxidant status. Food Chem. Toxicol., 45: 2267-2272.

5. Lantz RC, Chen GJ, Sarihan M, Solyom AM, Jolad SD, and Timmermann. (2007): The effect of extracts from ginger rhizome on inflammatory mediator production. Phytomedicine 14: 123-128.

6. Nicolll $R$, and Henein MY.(2007): Ginger (Zingiber officinale Roscoe): Ahot remedy for cardiovascular disease? Int. J. Cardiol..23: (Epub ahead of print).

7. Ali BH, Blunden G, Tanira MO, Nemmar A. (2008): Some phytochemical, pharmacological, and toxicological properties of ginger (Zingiber officinale Roscoe): A review of recent 
research. Food Chem. Toxocol., 46: 209-20.

8. Han (b) LK, Zheng YN, Yoshikawa M,Okuda $H$, and Kimura Y.(2005): Anti-obesity effects of chikusetsusaponins isolated panax japonicus rhizomes. BMC Complement Altern. Med., 5 : 9.

9. Joharchi $K$, and Jorjani $M$. (2007): The role of nitric oxide in diabetes induced changes of morphine tolerance in rats. Eurp. J. Pharm., 570: 66-71.

10. Perrot S, Guilbaud G, and Kayser V (1999): Effects of intra-planter morphine on paw edema and pain-related behavior in rat model of repeated acute inflammation. Pain 83: 249-257.

11. Weissman $M$, Klien $B$. Evaluation of glucose determination in untreated serum samples. Clin. Chem. 1958; 4: 420-422.

12. Allain CC, Poon LS, Chan CS, Richmond W, Fu PC (1974): Enzymatic determination of total serum cholesterol. Clin. Chem., 20(4) : 470 - 75 ..

13. McGowan MW, Artiss JD, Standbergh DR, Zak B (1983):

A peroxidase-coupled method for the colorimetric determination of serum triglycerides. Clin. Chem., 29 (3): 538542.

14. Assmann G, Jabs HU, Kohnert $U$, Nolte $W$ and Schriewer H(1984): LDL-cholesterol determination in blood serum following precipitation of LDL with polyvinylsulfate. Clin. Chim. Acta 140 (1): 77-83.

15. Bergmenyer(1981): Methods of enzymatic analysis, 3 rd edition, volum VIII, edited by HU 11: 145-160.

16. Buege JA and Aust SD (1978): Microsomal lipid peroxidation, modified by adding the BHT solution to prevent further lipid peroxidation during boiling. Method Enzymology 52: 302-10.

17. van Bezooijen RL, Que I, Ederveen AG, Klousterboer HJ, Papapoulos SE and Lovik LW(1998): Plasma nitrate and nitrite level are regulated by ovarian steroids but do not correlate with trabecular bone mineral density in rats. J. Endocrinology 159: 27-34.

18. Brueggemeier RW;Richards JA, and Petrel TA (2003): Aromatase and cyclooxygenases enzymes in breast cancer. J. Steroid Biochem. Mol. Biol., 86 (3-5) : 501.507.

19. Mitra B and Panja M.(2005): High sensitivity C-reactive protein: a novel biochemical marker and its role in coronary artery disease. J. Assoc. Physicians India 53: 25-32.

20. Thomson et al, Thomson KK, Al-Qattan SM, Al-Sawan MA, Alnaqeeb I, Khan and Ali M.(2002): The use of ginger (Zingiber officinale Rosc) as a potential anti-inflammatory and anti-thrombotic agent. Prostaglandins Leukotr. Essent. Fatty Acids 67: 475-478.

21. Verma SK, Singh $M$, Jain $P$, and Bordia A.(2004): Protective effect of ginger, (Zingiber officinale Rosc) on experimental atherosclerosis in rabbits. Indian J. Exp. Biol., 42: 736-738. 
22. Al-Amin ZM, Thomson M, AlQattan KK, Shalaby RP, and Ali M(2006): Anti-diabetic and hypolipidemic properties of ginger (Zingiber officinale) in streptozotocin-induced diabetic rats. British J. Nutrition 96; 660666.

23. Akhani SP, Vishwakarma SL, and Goyal RK (2004): Antdiabetic activity of Zingiber officinale in streptozotocininduced type I diabetic rats. J Pharma Pharmacol., 56: 101- 105.

24. Kadnur SV, and Goyal RK (2005): Beneficial effects of Zingiber officinale Roscoe on fructose induced hyperlipidemia and hyperinsulinemia in rats. Indian J. Exp. Biol., 43: 1161-4.

25. Ojewole JA(2006): Analgesic, inflammatory and hypoglycemic effects of extract of Zingiber officinale rhizomes in mice and rats. Thromb. Res., 20: 764-772.

26. Bordia A, Verma SK, and Srivastava KC (1997): Effect of ginger (Zingiber officinale Rosc) and fenugreek (Tringonella foenum-graecum L.) on blood lipids, blood sugar and platelet aggregation in patients with coronary artery disease. Prostagl. Leukotr. Essen. Fatty Acids 56: 379-384.

27. Lppoushi K, Azuma K, Lto H, Horie $H$, and Higashio $H$. (2003): (6)-gingerol inhibits nitric oxide synthesis in activated J774.1 mouse macrophages and prevents peroxynitrite-induced oxidation and nitration reactions. Life Science 73: 3427-3437.

28. Imanishi N, Mantani N, Sakai S, Sato M, Katada Y, Ueda K,
Terasawa K, Ochiai H. (2004): Inducible activity of ginger rizome (Zingeber offifinale Rosc) on the mRNA expression of macrophage-inducible nitric oxide synthase and NO production in a macrophage cell line, RAW264.7 cells. Am. J. Chin. Med., 32: 727- 35.

29. Asnani V, and Verma RJ. (2005): Antioxidative effect of Zinziber officinale on paraben induced lipid peroxidation: an in vitro study. Acta Pol. Pharm., 64: 35-7.

30. Suganthi R, Rajamani S, Ravichandran MK, Anuradha C (2007):V. Effect of food seasoning spices mixture on biomarkers of oxidative stress in tissues of fructose-fed insulinresistant rats. J. Med. Food 10: 149-53.

31. Kim Y, Na KM, Surh YJ, and Kim TY (2007): (6)-gingerol prevents UVB-induced ROS production and COX-2 expression in vitro and in vivo. Free Radic. Res., 41: 603-614.

32. de-Lemos ET, Reis F, Baptista S, Pinto R,Sepodes B, Valva $H$, Rocha- Pereira P, Silva AS, Teixeira F.(2007): Exercise training is associated with improved levels of C-reactive protein and adiponectin in ZDF (typ 2) diabetic rats. Med Sci Monit., 13 (8): BR 168- 74.

33. Amezcua-Guerra LM, Springall del Villar C, Bojalilparra R. (2007): C reactive protein cardiovascular issues of an acute phase protein. Arch Cardiol. Mex., 77: 58-66. 
34. Clapp BR, Hirschfield GM, Storry C, et al. (2005): Inflammation and endothelial function: direct vascular effects of human C-reactive protein on nitric oxide bioavailability. Circulation 111 (12): 1530 - 6.

35. Grzanna $R$, Lindmark $L$, and Frondoza CG. (2005): Ginger- an herbal medicinal product with broad ant-inflammatory action. J. Med. Food. 8: 125-132.

36. Tripathi S, Bruch D, and Kittur DS. (2008): Ginger extract inhibits LPS induced macrophage activation and function. BMC Complement Altern. Med.; 1: 8.

\section{التأثير النافع للجنزبيل كعامل خافض لنسبة السكرو الدهون فى الدم و مضاد

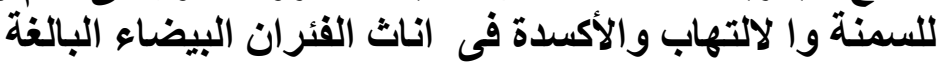

$$
\text { منى فاروق القرن* و سحر الدبك محمد و أمانى أوسامه محدد }
$$

قسمى الفيسيولوجيا الطبية** و الكيمياء الحيوية الطبية ـ كلية الطب، جامعة أسيوط لئه

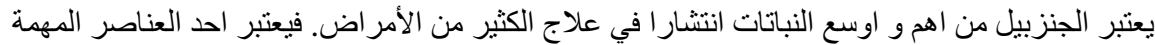

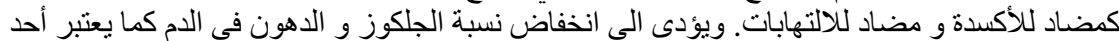

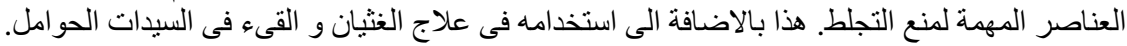

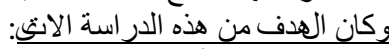
1- تقدير مدى التأثير النافع للجنزبيل فئ حالات الات السمنة وارتفاع نسبة السكر و الدهون فى الدم

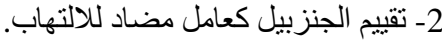

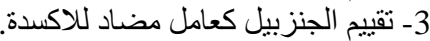

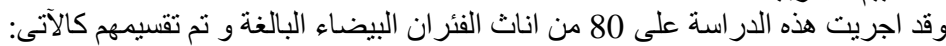

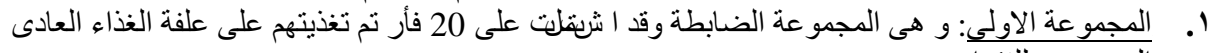
المخصص للفئر ان.

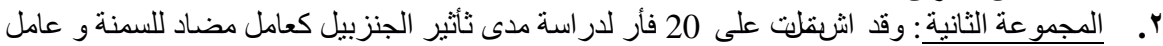

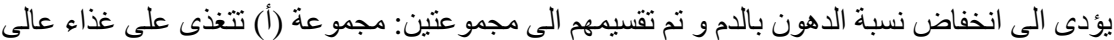

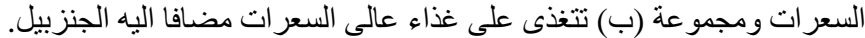

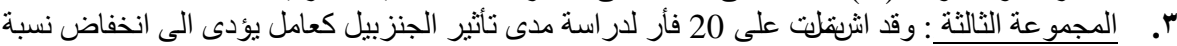

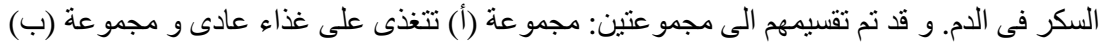
يضاف الى غذائها الجنزبيل.

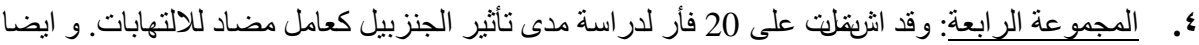

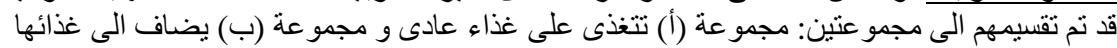

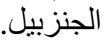
مدة التجربة 8 اسابيع منذ بداية العمل حتى سحب العينات.

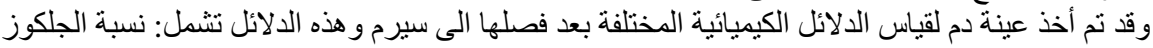

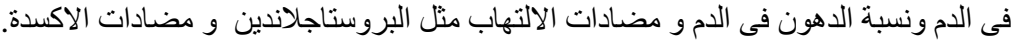

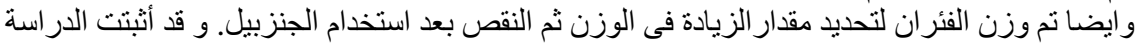

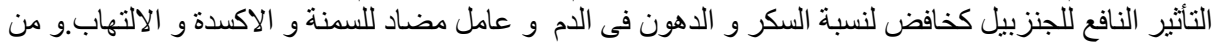

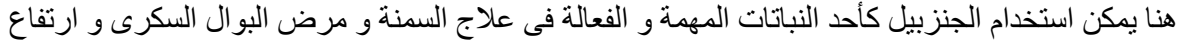

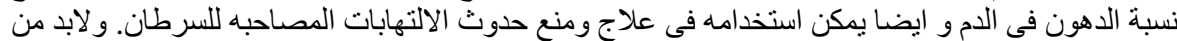
اجر اء الكثير من الدراسات لتحديد المادة الفعاله المسؤولة عن التناثثير النافع للجنزبيل. 